\title{
Bekymringsfullt om bekymringsverdig
}

\author{
Som fast leser av Tidsskriftet finner jeg det bekymringsfullt når en lederskribent finner noe bekymrings- \\ verdig, til og med flere ganger.
}

«Etter en bekymringsverdig økning sank antibiotikaforskrivningen $\mathrm{i}$ britisk allmennpraksis ganske betydelig i andre halvdel av 1990-årene» og «Svært mange vet ikke at det er helt vanlig - og ikke bekymringsverdig å hoste i flere uker ved akutt bronkitt,» sto det i en lederartikkel i nr. 14/2014 (1).

Jeg ble en gang oppfordret til å delta i en «språkrøktergruppe» for Tidsskriftet, noe jeg anså beundringsverdig! Språket skal riktignok være i endring, men det får holde med at «resultat» er blitt erstattet av anglisismen «utkomme» (outcome), som på norsk betyr noe helt annet, og at en «rolle» er blitt til en «karakter» (character), som var noe vi fikk på skolen, ikke noe vi spilte i en film eller på teater.

Det er ille når barn ikke kan uttale «skj» og «Østfold-l» invaderer selv de «kondisjonerte klasser», men la ikke bekymringen bli «verdig» i Tidsskriftet!

\section{Rolf Kirschner}

rolf.kirschner@getmail.no

Rolf Kirschner (f. 1946) er spesialist i fødselshjelp og kvinnesykdommer.

\section{Litteratur \\ 1. Høye S. Ikke spør legen. Tidsskr Nor Legeforen 2014; 134: 1341.}

\section{Redaksjonen svarer:}

Innlegget fra Rolf Kirschner viser - igjen hvor årvåkne Tidsskriftets lesere er. Det er helt riktig at ordet «bekymringsverdig» ikke finnes på norsk. Ifølge ordbøkene. Og ordbøkene skal vi jo holde oss til. Ingen tvil om det. Men så finnes ordet likevel. Per Egil Hegge fikk for et par år siden mer enn 50000 treff på Google (1). I tekst- arkivet Retriever får vi over 11000 treff, hvorav over 250 fra Hegges egen avis Aftenposten, senest i dagens utgave (12.8.2014). I bokhylla.no får vi ca. 700 treff i bøker, blant annet hos Jan Kjærstad og i Norges offentlige utredninger. Ordet finnes altså rundt oss overalt, og det er ikke så rart at noen hver da tar det $\mathrm{i}$ bruk.

I tillegg til at det er mye brukt, er det også en logikk i det. Mange vil skjelne mellom bekymringsverdig og bekymringsfull på denne måten: En situasjon som gir grunn til bekymring, er bekymringsverdig, mens en bekymret person er bekymringsfull (1). Man forstår hva som menes, ordet bekymringsverdig bringer liten forvirring, så å si. $\AA$ bruke det er en synd som det finnes tilgivelse for. Og hvem vet: Kanskje det etter hvert blir så vanlig at det kommer inn i ordbøkene? Det er jo slik at hvis bare mange nok gjør en språkfeil mange nok ganger, blir feilen til slutt «riktig». Og da vil leksikografene ta ordet med i neste utgave av ordboken (2). Eller med lovgiveren Justinians (ca. 482-565) ord: Communis error facit ius (felles feil skaper regel).

Kirschner nevner også ordet «utkomme», som virkelig florerer i medisinske manuskripter. Betydningen av «utkomme» er inntekt eller midler til livets opphold, ifølge ordbøkene (3). Det gjelder også på svensk og dansk. Men når «utkomme» brukes i medisinen, er meningen ofte en helt annen, nemlig resultat eller utfall, som er betydningen av det engelske ordet «outcome». Dette er et eksempel på en såkalt falsk venn, dvs. to ord på to ulike språk, der ordene har tilnærmet lik ordlyd, men ikke samme betydning (3). Falske venner er åpenbart dårligere selskap enn ekte venner. Man bør rett og slett holde seg unna dem, uansett om de er aldri så vanlige.

Erlend Hem

erlend.hem@medisin.uio.no

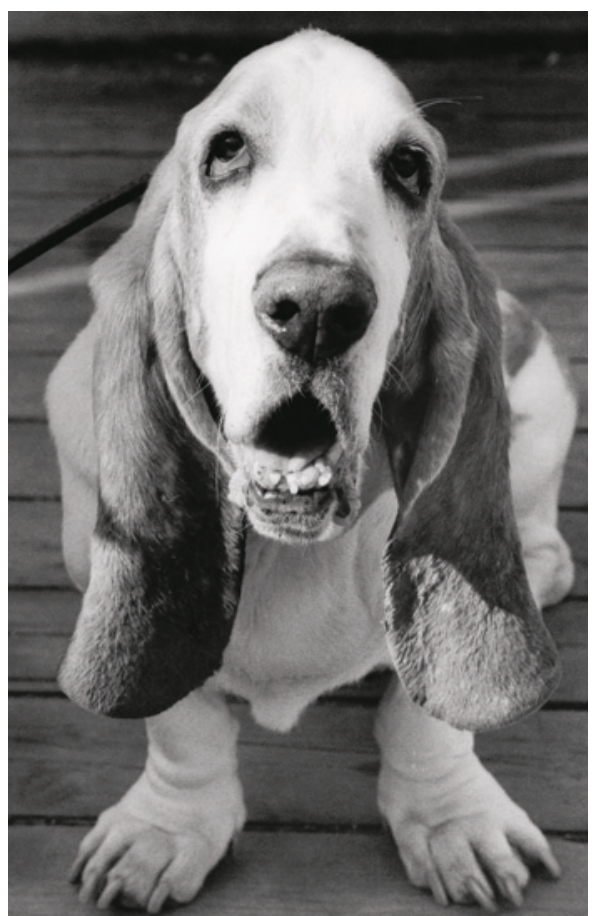

Illustrasjonsfoto: NTB scanpix

Erlend Hem (f. 1970) er dr.med. og assisterende sjefredaktør i Tidsskriftet.

Litteratur

1. Hegge PE. Bekymringsfullt. Aftenposten 10.10.2012: 4 http://tux.aftenposten.no/spraak/ spraak?action=question\&id=4789 $(12.8 .2014)$

2. Hem E. Smittsom speiling. Tidsskr Nor Legeforen 2010; 130: 1502

3. Flo $\AA$. Om penger og falske venner. Tidsskr Nor Lægeforen 2007; 127: 2423. 